\title{
COMPARATIVE ANALYSIS OF FLOODED AREAS USING SATELLITE IMAGES LANDSAT 7-ETM+ AND HYDRAULIC MODEL HEC-RAS. CASE STUDY: THE JIJIA RIVER, SLOBOZIA-DINGENI SECTION
}

DOI: http://dx.doi.org/10.18509/GBP.2019.72

UDC: 561.311.2:[528.8:629.783.05(498)

\author{
ElenaHuțanu \\ Andrei Urzică \\ Larisa Elena Paveluc \\ Cristian Constantin Stoleriu \\ Adrian Grozavu \\ Alexandru Ioan Cuza University of Iasi, Faculty of Geography and Geology, \\ Department of Geography, Iasi, Romania
}

\begin{abstract}
This study aims to make a comparison between flooded areas identified using the flood bands obtained with HEC-RAS hydraulic model, and the NDWI index resulted by processing Landsat 7-ETM+ satellite imagery. The study area was the upper sector of the Jijia River in Moldavian Plateau (North-Eastern Romania), affected by the July 2010 flood that was well caught in the satellite images. During that event the level of the Jijia River at Dingeni hydrometric station reached a value of $579 \mathrm{~cm}$, far exceeding the level of flooding. Performing different flood simulations on the concerned river sector, a flooded area of $15.80 \mathrm{~km}^{2}$ has been revealed when applied the NDWI index, and a flooded area of $16.26 \mathrm{~km}^{2}$ when used the HEC-RAS hydraulic model. Following the field analysis, the values obtained with HEC-RAS are validated. The flooded area smaller by $0.46 \mathrm{~km}^{2}$ in the case of images Landsat 7-ETM+ could be explained by errors due to resolution or cloudiness.
\end{abstract}

Keywords: flood, GIS, remote sensing, NDWI, HEC-RAS, Jijia River

\section{INTRODUCTION}

Flooding is the most common phenomenon of global hydrological risk. The location of many dwellings and other economic facilities in potentially flooded areas leads to increased economic losses as well to increased risk of losing human lives. That is why identification of potentially floodable areas is essential for reducing damage in the event of a flood.

Various methods can be used for mapping flood [1-4]. Many studies apply the HEC-RAS hydraulic model and the NDWI index obtained by processing satellite imagery. The methodology HEC-RAS is designed to achieve a more precise simulation of floods, while satellite images, as part of the remote sensing, allow GIS processing by means of indices (MNDWI, NDVI, AWEI, ML or NDWI) depending on the type of information to be extracted. Recently, methodological studies aiming at producing such maps have multiplied, benefiting from the generalization of Geographic Information Systems (GIS) [5], the spectacular increase in the sources of acquisition of spatial data and the development of statistical models to explain and predict natural phenomena $[6,7]$.

The present study aims to identify and compare the potentially floodable areas of the upper sector of the Jijia River in North-Eastern Romania, obtained by using two methods: 
the HEC-RAS hydraulic model, and the NDWI index resulted by processing satellite imagery. These two methods have been used in numerous studies at both international [811] and national [12-14] levels, contributing to the improvement of flood risk mapping.

\section{STUDY AREA}

The Jijia River is the tributary of the Prut River, located in the in the Moldavian Plateau in the north-eastern part of Romania. From an administrative point of view, the Jijia river basin is part of the Botosani and Iasi counties. The Slobozia-Dingeni sector is located in the central part of Botosani County, stretching between the Dorohoi hydrometric station (located upstream of the studied sector) and Dingeni hydrometric station (located downstream of the studied sector). The main localities in the studied sector are Slobozia, Vladeni, Borzesti, Ungureni and Dingeni (Fig.1). The Jijia River's multi-annual average flow is $0,83 \mathrm{~m}^{3} / \mathrm{s}$, but maximum flows registered at both stations are over $100 \mathrm{~m}^{3} / \mathrm{s}$. From the climatic point of view, the average annual precipitation amount is between 550 and $600 \mathrm{~mm}$, and the average air temperature is between 9 and $9,5^{\circ} \mathrm{C}$.

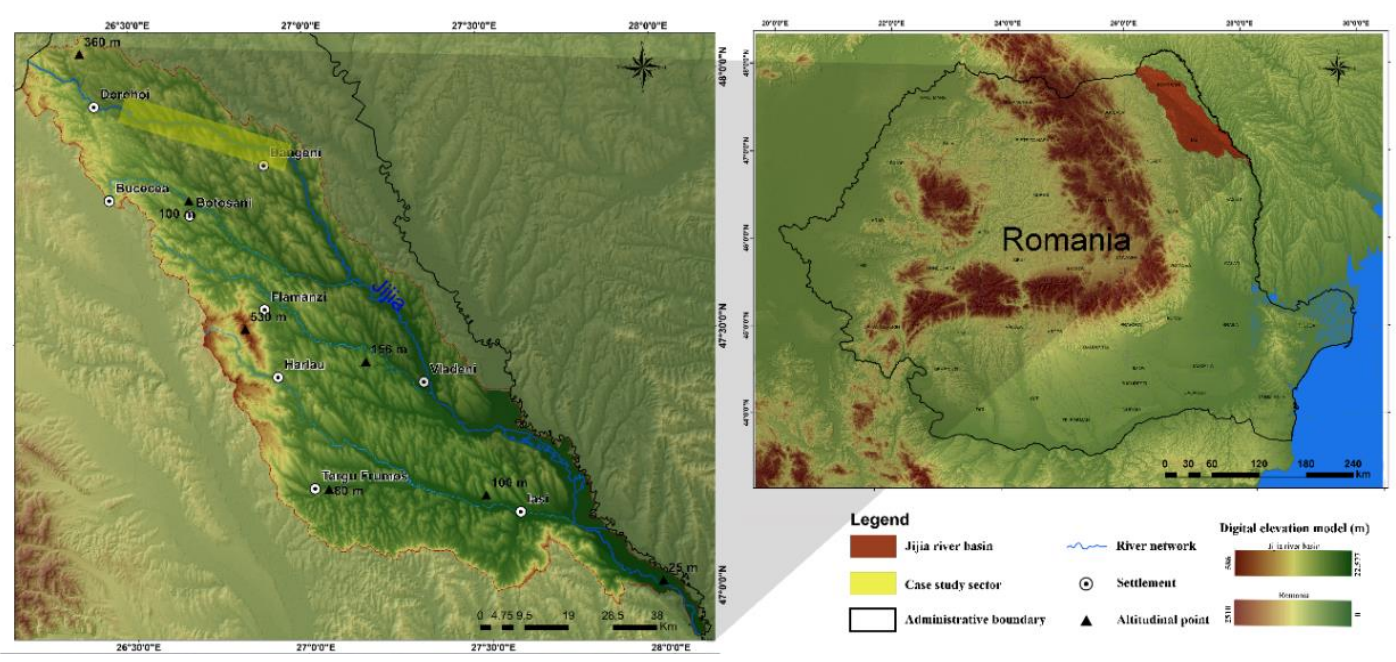

Figure 1. Location of the study area in NE Romania

The geological deposits specific to the Jijia hydrographic basin belong to the Sarmatian (Bassarabian), being represented by alternating layers of clays, marls, sandstone, sands and loams [15]. The deposits of the floodplain belong to the Upper Pleistocene and Holocene, mainly constituted of gravel, sands and loams. Climatic characteristics, vegetation and rock type of Jijia river valley facilitated the development of Aluviosol soils. Also in the floodplain area there are Solonetz soil areas [2].

\section{METHODOLOGY}

As already mentioned, we used two methods of identifying the areas at risk from flooding. The first method is the creation of a flood band with the HEC-RAS hydraulic model, and the second method consists in processing the Landsat 7-ETM + images using the NDWI index, taking into account the strong floods of July 2010.

HEC-RAS Method. In order to model the floodplain in HEC-RAS, in the first stage, it was necessary to digitize the relief elements, as the basis for modeling the floodable areas. The spatial database was extracted from a Digital Terrain Model (DTM) obtained by LiDAR technology (DTM resolution of $0.5 \mathrm{~m}, 1: 5,000$ ) and aerial images (orthophoto 
maps with a resolution of $0.5 \mathrm{~m}, 1: 5,000)$. Vector digitization and simulation of flood strips were made using ArcGIS software, HEC-RAS and HEC-GeoRAS extensions. In order to simulate the flooding, it was necessary to generate vector strata such as: the slope of the Slobozia-Dingeni sector, which coincides with the drainage channel, the banks of the minor bed, the floodplain, the land use, as well as the transverse profiles with an equidistance of approximately $20 \mathrm{~m}$. The HEC-RAS simulation of the flood, based on the LiDAR type elevation raster, generated a .tin file. The flood simulation was generated by entering the flow recorded on June 28th, $2010\left(190 \mathrm{~m}^{3} / \mathrm{s}\right)$. On July 3rd, according to Landsat $7 \mathrm{ETM}+$ images, the water was not withdrawn.

Landsat 7-ETM + image processing method using the NDWI index. For the implementation of the second method, two important steps were taken: the data acquisition and processing stage. Thus, a set of data in raster format (Landsat 7-ETM + images) has been achieved, which are open source. The data processing involved a series of operations that included raster and vector files. Six indices for the identification of water bodies (MNDWI, NDWI, NDVI, AWI, WRI, and NDMI) were first calculated. This operation was required to get the most accurate model. Of the six calculated indices, the NDWI index was chosen. The next step was to extract the flood limit of the index/index that was also used in the next processes. The obtained limit was validated and brought to the local projection system [13]. In the last stage of the study the results obtained with both methods were compared and the differences between them were identified by extracting the land use based on the flood limit, calculating the flooded areas, generating the descriptive statistics, but also creating suggestive cartographic material.

\section{RESULTS AND DISCUSSIONS}

The floods produced at the end of June and early July 2010 had a duration of 7 days. The water level reached a maximum of $874 \mathrm{~cm}$ at Dorohoi, $274 \mathrm{~cm}$ higher than the flood rate, and $579 \mathrm{~cm}$ at Dangeni, $96 \mathrm{~cm}$ more than the flood rate, the flood resulting in countless damages, including the total destruction of dozens of dwellings [13].

Processing data through the two methods has led to identification of a total flooded area of $16,2 \mathrm{~km}^{2}$ by using the HEC-RAS method, respectively, of an area of $15,8 \mathrm{~km}^{2}$ by using the NDWI index method. Thus, a percentage of approximately $60 \%$ of the flodplain area was flooded, the difference between the floded areas obtained by both methods being only $0.4 \mathrm{~km}^{2}$ (Table 1 ).

In terms of land use, from the total flooded area obtained by the Hec-RAS method, residential areas occupy about $0,17 \mathrm{~km}^{2}$, compared to the surface obtained using the NDWI index, the former being higher with only $0,04 \mathrm{~km}^{2}$ compared to the second one. This represents $10 \%$ of the total area occupied by residential areas. According to the NDWI index, the residential zone occupy about $0.13 \mathrm{~km}^{2}$, which represents $0.47 \%$ of the total flodplain area. Of the total residential zone that is present in the flodplain, the flooded residential areas occupy about $7.87 \%$, the difference indicated by the two methods being $2.92 \%$ (Table 1).

Industrial or commercial units have a flooded surface of $0.15 \mathrm{~km}^{2}$ as indicated by the HEC-RAS method, respectively $0.17 \mathrm{~km}^{2}$ according to the NDWI index method, so the difference between the two methods is $0,02 \mathrm{~km}^{2}$. Of the total flodplain area, the areas occupied by the industrial or commercial units represent $0.56 \%$ (HEC-RAS method), respectively $0.62 \%$ (NDWI), and $86.37 \%$ respectively $95.4 \%$ of the total industrial and commercial units that are present in the flodplain of the studied sector (Table 1). 
Table 1. Areas affected by the flood in July 2010, related to the flooded area and the total area of the flodplain in the Slobozia-Dingeni sector

\begin{tabular}{|c|c|c|c|c|c|c|c|c|c|c|}
\hline \multicolumn{3}{|c|}{ Floodplain information } & \multicolumn{4}{|c|}{ NDWI } & \multicolumn{4}{|c|}{ HEC-RAS } \\
\hline \multirow{2}{*}{$\begin{array}{c}\begin{array}{c}\text { Land } \\
\text { use } \\
\text { category }\end{array} \\
{ }^{4} \text { Code }\end{array}$} & \multicolumn{2}{|c|}{$\begin{array}{l}\text { Floodplain } \\
\text { surface }\end{array}$} & \multicolumn{2}{|c|}{$\begin{array}{l}\text { Flooded } \\
\text { affected }\end{array}$} & \multirow{2}{*}{$\begin{array}{c}\begin{array}{c}\text { Flood- } \\
\text { plain } \\
\text { affected }\end{array} \\
2 \%\end{array}$} & \multirow{2}{*}{$\begin{array}{c}\text { Affected } \\
\text { land use } \\
\text { category }\end{array}$} & \multicolumn{2}{|c|}{$\begin{array}{l}\text { Flooded } \\
\text { affected }\end{array}$} & \multirow{2}{*}{$\begin{array}{c}\begin{array}{c}\text { Flood- } \\
\text { plain } \\
\text { affected }\end{array} \\
2 \%\end{array}$} & \multirow{2}{*}{ 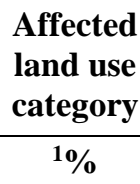 } \\
\hline & $\mathbf{k m}^{2}$ & $\%$ & $\mathrm{~km}^{2}$ & $3 \%$ & & & $\mathbf{k m}^{2}$ & $3 \%$ & & \\
\hline 1121 & 1.61 & 6.00 & 0.13 & 0.80 & 0.47 & 7.87 & 0.17 & 1.07 & 0.65 & 10.79 \\
\hline 1113 & 0.17 & 0.65 & 0.17 & 1.04 & 0.62 & 95.40 & 0.15 & 0.92 & 0.56 & 86.37 \\
\hline 1212 & 0.56 & 2.10 & 0.41 & 2.56 & 1.51 & 71.80 & 0.29 & 1.78 & 1.08 & 51.22 \\
\hline 1211 & 0.44 & 1.62 & 0.17 & 1.05 & 0.62 & 38.24 & 0.08 & 0.51 & 0.31 & 18.91 \\
\hline 2321 & 0.84 & 3.13 & 0.18 & 1.14 & 0.67 & 21.39 & 0.18 & 1.09 & 0.66 & 21.03 \\
\hline 2331 & 0.08 & 0.30 & 0.02 & 0.13 & 0.08 & 26.20 & 0.02 & 0.15 & 0.09 & 30.68 \\
\hline 2111 & 11.12 & 41.4 & 7.04 & 44.5 & 26.26 & 63.38 & 7.58 & 46.5 & 28.26 & 68.20 \\
\hline 6221 & 0.02 & 0.07 & 0.01 & 0.06 & 0.03 & 47.72 & 0.01 & 0.06 & 0.04 & 52.06 \\
\hline 3411 & 0.31 & 1.14 & 0.21 & 1.36 & 0.80 & 70.33 & 0.27 & 1.68 & 1.02 & 89.42 \\
\hline 3131 & 0.07 & 0.26 & 0.00 & 0.03 & 0.02 & 5.99 & 0.00 & 0.02 & 0.01 & 5.05 \\
\hline 4221 & 10.86 & 40.5 & 6.88 & 43.5 & 25.64 & 63.31 & 6.81 & 41.8 & 25.37 & 62.65 \\
\hline 9111 & 0.59 & 2.21 & 0.54 & 3.42 & 2.02 & 91.01 & 0.57 & 3.50 & 2.13 & 96.00 \\
\hline 9121 & 0.04 & 0.14 & 0.03 & 0.19 & 0.11 & 81.91 & 0.03 & 0.21 & 0.13 & 94.20 \\
\hline 9113 & 0.01 & 0.06 & 0.01 & 0.09 & 0.06 & 100 & 0.01 & 0.05 & 0.03 & 58.06 \\
\hline 7111 & 0.10 & 0.39 & 0.00 & 0.02 & 0.01 & 2.50 & 0.06 & 0.39 & 0.24 & 61.69 \\
\hline Total & 26.83 & 100 & 15.8 & 100 & 58.91 & 58.91 & 16.28 & 100 & 60.67 & 60.67 \\
\hline \multicolumn{11}{|c|}{ 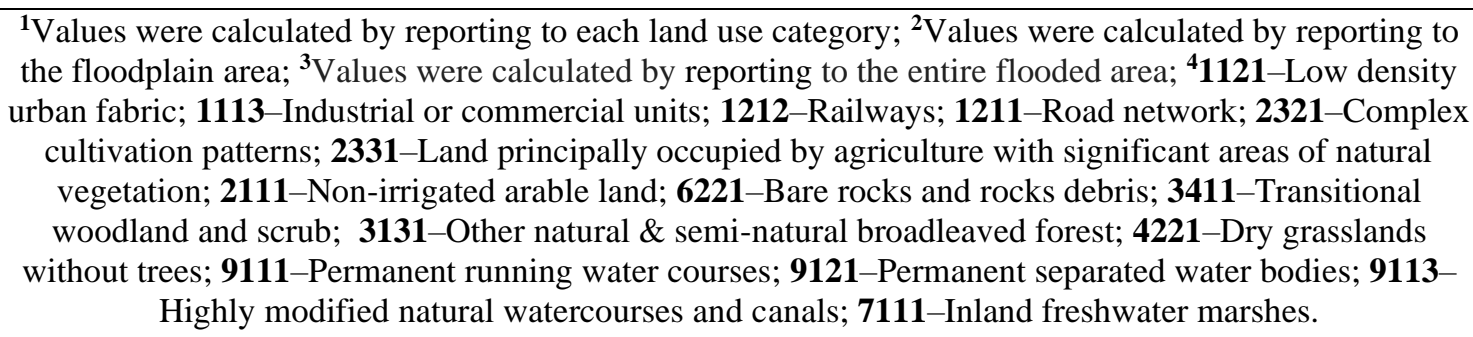 } \\
\hline
\end{tabular}

Railways and associated terrain were flooded at a rate of $71.80 \%$, on an area of $0.41 \mathrm{~km}^{2}$, representing $2.56 \%$ of the flooded area and $1.51 \%$ of the total flodplain according to the NDWI index. According to the HEC-RAS method, they were flooded at a rate of $51.22 \%$ on an area of $0.29 \mathrm{~km}^{2}$, the difference between the areas obtained by the two methods being $20 \%$. This difference is due to the fact that the Landsat images were unable to capture the small areas that are not flooded inside the band, and they require much better accuracy. The road network accounts for $0.31 \%$ of the total flodplain area of the SloboziaDingeni sector. As a result of the analysis using the NDWI index, $38.24 \%$ is flooded, and according to HEC-RAS, $18.91 \%$ is flooded, the difference between the two methods being, as in the case of the railways, about $20 \%$ (Table 1).

The arable land presents the largest areas of the entire flodplain of the studied sector (11.1 $\mathrm{km}^{2}$ ), followed by pastures, with an area of $10.8 \mathrm{~km}^{2}$. According to the NDWI index, nonirrigated arable land has a flooded area of $7.04 \mathrm{~km}^{2}$, representing about $44.58 \%$ of the total flooded area, $26.26 \%$ of the total flodplain and $63.38 \%$ of the total arable land present in the flodplain of the sector. Referring to the HEC-RAS method, flooded arable land has a surface area of $7.58 \mathrm{~km}^{2}$, representing $46.5 \%$ of the total flooded area and 
$68.2 \%$ of the total area of this use category. The difference identified by the two methods is very small, in both cases the arable train presenting the largest flooded area.

The second category of land use that have large flooded areas is dry grasslands which, according to the application of the NDWI index, occupy $6,88 \mathrm{~km}^{2}$, with a share of $43.52 \%$ of the total flooded area. Areas with flooded pastures occupy $25.64 \%$ of the total flodplain and $63.31 \%$ of the total pastures that are present in the flodplain. Following the HECRAS flood simulation, the flooded area occupied by the pastures is $6.81 \mathrm{~km}^{2}$, representing $41.8 \%$ of the total flooded area and $62.65 \%$ of the total category of use from the flodplain of the studied sector.

Figure 2. shows the flood bands obtained by the two methods. As can be seen, both the NDWI and HEC-RAS flood grid maintain approximately the same conformation of the polygon in most flooded areas, but there are major differences inside the polygon. The polygon obtained with the NDWI index is compact, appearing to be completely flooded, while the flood band obtained using the HEC-RAS method is fragmented, showing inland polygons unaffected by flooding. The most representative non-flooded polygons are those created by the road network. These are also highlighted by the large difference between the road and railway area obtained in HEC-RAS and that obtained with the NDWI index. The level difference between the non-flooded areas of the band and the flooded ones is approximately $0.5 \mathrm{~m}$.

\section{CONCLUSIONS}

For the study, two methods of making the bands of inundability were compared. The first method was to simulate a flood using the HEC-RAS hydraulic model to which the flow recorded during the July 2010 flood was introduced, and the second method was to extract water bodies from Landsat 7-ETM + images using the NDWI. Following the study, the bands of inundability were obtained with the $16.2 \mathrm{~km}^{2}$ with the HEC-RAS method and $15,8 \mathrm{~km}^{2}$ with the NDWI method.

Regarding the category of land use, the biggest differences between flooded areas were identified in the case of railway and road, the difference being of about $20 \%$. Of the total use categories, the largest flooded areas are arable land and pasture land, the values being obtained with both methods.

The analysis of the two obtained polygons reveals a major difference between them. Although the shape of both polygons is approximately the same, the flood band is compact compared to that obtained in HEC-RAS, which has non-flooded inner polygons. These differences are explained by the fact that the Landsat image has a much lower resolution than the LiDAR data that was the main support for the HEC-RAS flood simulation. Another factor that may prevent water bodies from detecting Landsat images is the cloudiness, clouds obstructing the identification of some flooded or non-flooded areas. 


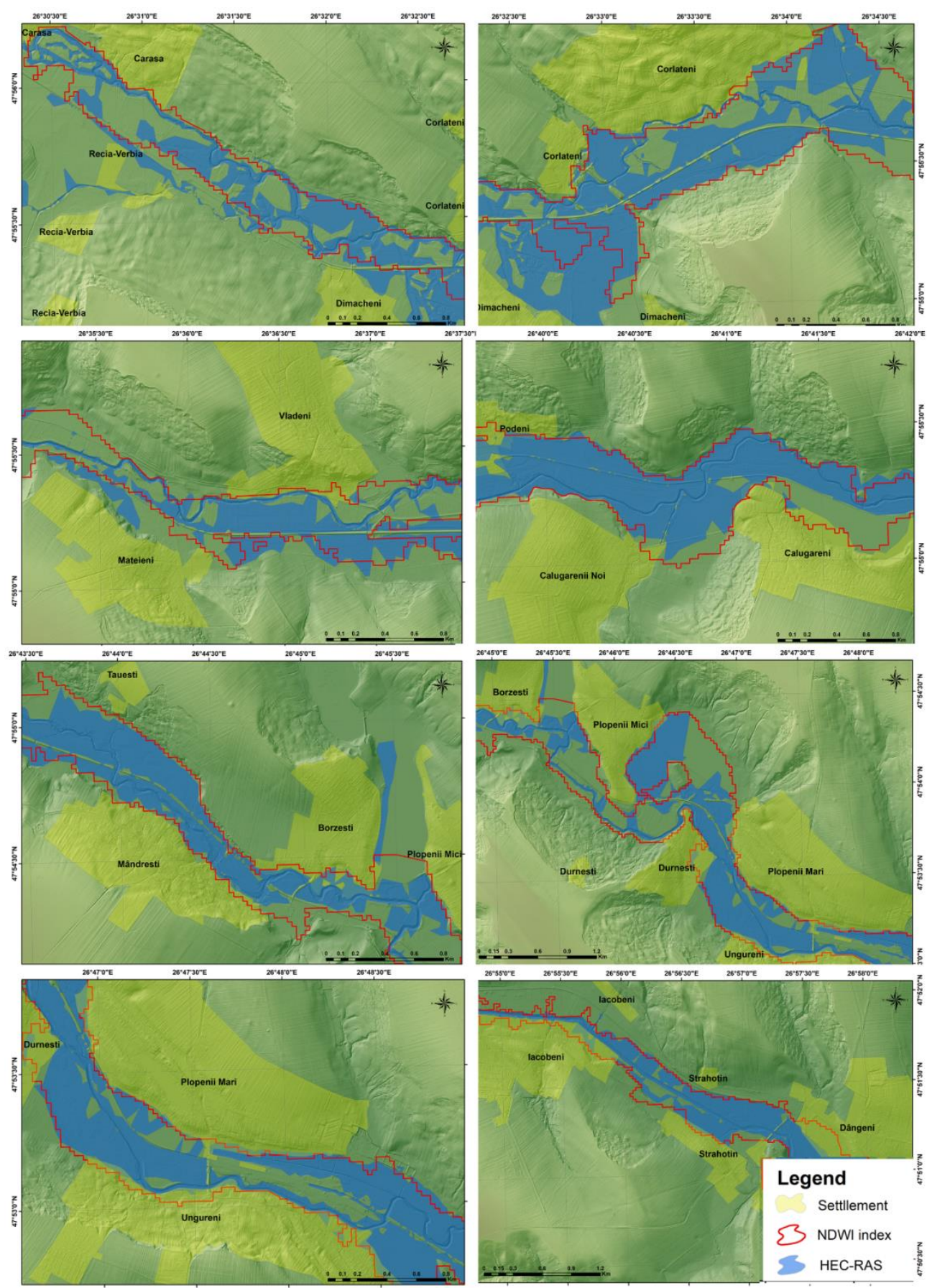

Figure 2.The difference between the areas affected by the floods in July 2010 obtained using the NDWI index and the HEC-RAS method

\section{REFERENCES}

[1] Feyisa G. L., Meilby H., Fensholt R. \& Proud, S. R. Automated Water Extraction Index: A new technique for surface water mapping using Landsat imagery, Remote Sensing of Environment, vol. 140, pp.23-35, 2014.

[2] Hutanu E., Mihu-Pintilie A. \& Urzica A. The use of GIS techniques for obtaining potentially floodable surfaces in the jijia floodplain, Geobalcanica 4th International Scientific Conference, 2018, Republic of Macedonia, pp. $473-480$. 
[3] Romanescu G., Cimpianu C.I., Mihu-Pintilie A. \& Stoleriu C.C. Historic flood events in NE Romania (post-1990), Journal of Maps, United Kingdom, vol. 13, pp. 787-798, 2017.

[4] Urzica A., Mihu-Pintilie A, Hutanu E, Ghindaoanu V.B. \& Albu L.M. Using GIS methods for modelling exceptional flood events in Baseu river basin, NE Romania, Geobalcanica 4th International Scientific Conference, 2018, Republic of Macedonia, pp. 463 - 471.

[5] Longley P.A., Goodchild M, Maguire D.\& Thind D. Geographical Information Systems and Science, England, Edit. John Wiley \& Sons, 2005.

[6] Romanescu G. \& Stoleriu C.C. Exceptional floods in the Prut basin, Romania, in the context of heavy rains in the summer of 2010, Natural Hazards and Earth System Sciences, Germany, vol. 17, pp. 381-396, 2017.

[7] Tošić R., Lovrić N., Dragićević S. \& Manojlović S. Assessment of torrential flood susceptibility using GIS matrix method: case study - VRBAS river basin (B\&H), Carpathian Journal of Earth and Environmental Sciences, vol. 13, no. 2, pp. 369-382, 2018.

[8] Systems B., Dyhouse G., Hatchett J, Benn J. Floodplain Modeling Using HEC-RAS, Bentley Insitute Press, Exton, Pennsylvania, 2003.

[9] Rokni K., Ahmad A., Selamat A. \& Hazini S. Water feature extraction and change detection using multitemporal Landsat Imagery, Remote sensing, vol. 6, pp. 4173-4189, 2014.

[10] Tamta, K \& Bhadauria H. S. Object-Oriented Approach of Landsat Imagery for Flood Mapping, International Journal of Computer Applications, Vol. 122(16), 2015.

[11] Wang Y., ColbyJ. D. \& Mulcahy K. A. An efficient method for mapping flood extent in a coastal floodplain using Landsat TM and DEM data, International Journal of Remote Sensing, vol. 23(18), pp. 3681-3696, 2002.

[12] Enea A., Urzica A. \& Breaban I.G. Remote Sensing, GIS and HEC-RAS techniques, applied for flood extent validation, based on Landsat Imagery, LiDAR and hydrological data. Case study: Baseu River, Romania, J Environ. Prot. Ecol, vol. 19, pp. 1091-1101, 2018.

[13] Hutanu E., Urzica A. \& Enea A. Evaluation of damages caused by flood, based on satellite images. Case study: Jijia River, Slobozia-Dângeni Sector, July 2010", Present Environment and Sustainable Development Conference, Romania, 2018, pp. 135-146.

[14] Romanescu G., Mihu-Pintilie A., Stoleriu C.C., Carboni D., Paveluc L.E. \& Cimpianu C.I. A Comparative Analysis of Exceptional Flood Events in the Context of Heavy Rains in the Summer of 2010: Siret Basin (NE Romania) Case Study. Water, Romania, pp 1-17, 2018.

[15] Branzila M., Geologia partii sudice a Campiei Moldovei, Ed. Corson, 221 p., Iasi, 1999. 